\title{
Analysis of Mathematical Reasoning Ability of Pre-Service Mathematics Teachers in Solving Algebra Problem Based on Reflective and Impulsive Cognitive Style
}

\author{
Analisis Kemampuan Penalaran Matematis Mahasiswa Calon Guru Matematika \\ dalam Menyelesaikan Masalah Aljabar Berdasarkan Gaya Kognitif Reflektif dan \\ Impulsif
}

\author{
Ayu Faradillah (*)
}

Universitas Muhammadiyah Prof. DR. HAMKA, Jl. Tanah Merdeka, Jakarta Timur

\author{
Received: March 10, 2018 \\ Revised: July 8, 2018 \\ Accepted: July 9, 2018
}

\begin{abstract}
The purpose of this research was to describe preservice teachers' mathematical reasoning ability in solving algebra problem based on reflective and impulsive cognitive style. Therefore, the total subject of this research is two pre-service teacher who has the cognitive style different from each other. It means that the subject of this research is one preservice teacher who has reflective cognitive style and one pre-service teacher who has an impulsive cognitive style. In addition, the category of research method used is explorative research with the qualitative approach where researchers tried to describe the mathematical reasoning ability of pre-service teachers in solving the mathematical problem according to cognitive style. As for the components of mathematical reasoning ability in this research are analysis, generalization, synthesis, justifying and nonroutine problem-solving. According to the components, there was one subject who could analyze the given problem while the others subjects could not. Moreover, all of the subjects have a difficulty in another component.
\end{abstract}

Keywords: Mathematical reasoning ability, algebra problem, cognitive style

(*) Corresponding Author:

083876230484

How to Cite: Faradillah, A. (2018). Analysis of mathematical reasoning ability of pre-service mathematics teachers in solving algebra problem based on reflective and impulsive cognitive style. Formatif: Jurnal Ilmiah Pendidikan MIPA, 8 (2), 119-128. http://dx.doi.org/10.30998/formatif.v8i2.2333

\section{PENDAHULUAN}

Pembelajaran matematika selalu berkaitan dengan permasalahan dalam kehidupan sehari-hari. Leonard (2013) berpendapat matematika yang merupakan ilmu yang universal, yang mendasari perkembangan teknologi modern, mempunyai peran penting dalam berbagai disiplin dan mengembangkan daya pikir manusia. Matematika timbul berdasarkan hasil pemikiran manusia yang berhubungan dengan ide, proses, dan penalaran. Sebagaimana yang dikatakan oleh Sa'adah (2010: 10) mengatakan bahwa materi matematika dan penalaran matematika tidak dapat dipisahkan. Hal ini dikarenakan, matematika dipahami melalui penalaran dan penalaran dipahami dan dilatih melalui materi matematika. Sehingga kemampuan penalaran matematis sangat penting dan dibutuhkan dalam mempelajari matematika. Selanjutnya Castro (2004: 2) said that mathematical reasoning as a part of mathematical thinking that involves forming 
Formatif: Jurnal Ilmiah Pendidikan MIPA

Vol. 8, No. 2, Agustus 2018, pp. 119-128

p-ISSN: 2088-351X

e-ISSN: 2502-5457

DOI: http://dx.doi.org/10.30998/formatif.v8i2.2333

generalizations and drawing valid conclusions about ideas and how they are related. Hal ini, mengidentifkasikan bahwa seseorang yang memiliki kemampuan penalaran matematis akan mampu untuk menggeneralisasikan suatu masalah sehingga membentuk suatu simpulan yang valid. Sumarmo (2013: 148) mengungkapkan bahwa penalaran merupakan proses berpikir dalam proses penarikan simpulan. Hal ini diperkuat oleh pendapat Shadiq (Hidayat, 2014: 59) menyebutkan bahwa penalaran merupakan aktivitas berpikir untuk menarik simpulan atau membuat suatu pernyataan baru berdasarkan beberapa pernyataan yang diketahui benar atau dianggap benar yang disebut premis. Kemampuan penalaran itu tidak statis, tetapi berkembang melalui pengalaman dan dibawakan dengan lebih mudah melalui latihan. Kemampuan penalaran adalah kemampuan siswa dalam menarik simpulan berdasarkan informasi yang ada dan dapat dibuktikan kebenarannya.

Oleh karena itu, mahasiswa calon guru harus memiliki kemampuan penalaran matematis yang baik sehingga mahasiswa mampu mengaplikasikan ke dalam proses pembelajaran di sekolah. Hal ini diperkuat oleh Baroody (Widyasari, 2013) mengungkapkan bahwa seorang penalar yang baik harus diperkenalkan dengan situasisituasi permasalahan yang berhubungan dengan penalaran sedini mungkin termasuk dalam pembelajaran matematika di sekolah.

Kemampuan penalaran matematis dapat membantu mahasiswa melihat matematika sebagai sesuatu yang logis dan masuk akal, sehingga dapat membantu mengembangkan keyakinan mahasiswa bahwa matematika merupakan sesuatu yang mereka dapat pahami, pikirkan, justifikasi, dan evaluasi. Berdasarkan beberapa pendapat di atas menunjukkan bahwa kemampuan penalaran matematis merupakan aspek penting yang harus mendapat perhatian dan harus dimiliki oleh mahasiswa calon guru matematika.

Hal ini dikarenakan ketika mahasiswa calon guru telah menjadi seorang guru professional, kemampuan penalaran matematis yang ia miliki mampu mengarahkan atau melatih siswanya untuk memiliki kemampuan penalaran matematis juga. Sehingga ia mampu menyelesaikan masalah-masalah matematika dengan pemikiran logisnya. Masalah adalah suatu situasi dimana seorang individu atau kelomppok disebut terbuka untuk melakukan suatu tugas untuk hal mana yang tidak ada algoritma, siap dan dapat diterima sebagai suatu metode pemecahannya. Sinaga (2016:172) mengatakan jika jawaban suatu masalah telah diperoleh maka hal itu tidak lagi disebut masalah. Permasalahan matematika beberapa bentuk di antaranya soal rutin dan soal non-rutin. Permasalahan non-rutin dalam arti soal yang tidak sering dimunculkan dalam soal-soal matematika. Soal non-rutin sangat efektif untuk selalu diterapkan dalam pembelajaran matematika untuk melatih daya nalar dan berpikir kritis dalam memecahkan masalah.

Masalah matematika non rutin dalam penelitian ini difokuskan pada aljabar yaitu soal aljabar matematika yang tidak bisa diselesaikan secara langsung atau soal yang tidak bisa diselesaikan dengan prosedur rutin. Oleh karena itu, mahasiswa calon guru matematika haruslah memiliki kemampuan penalaran matematis yang tinggi untuk dapat menggunakan masalah non-rutin tersebut. Hal ini, mengindikasi bahwa sebelum menjadi seorang guru, haruslah dianalisis terlebih dahulu sejauh mana tingkat kemampuan penalaran yang dimiliki mahasiswa calon guru.

Objek-objek yang dikaji dalam matematika bersifat abstrak sehingga mahasiswa calon guru perlu menggunakan daya bernalarnya untuk menyelesaikan soal yang diberikan. Ketika mahasiswa calon guru mengalami kesulitan dalam mengasah kemampuan penalaran matematisnya, mahasiswa seringkali ceroboh dalam menyelesaikan masalah tersebut. Kecerobohan merupakan salah satu kebiasaan yang 
Formatif: Jurnal Ilmiah Pendidikan MIPA

Vol. 8, No. 2, Agustus 2018, pp. 119-128

p-ISSN: 2088-351X

e-ISSN: 2502-5457

DOI: http://dx.doi.org/10.30998/formatif.v8i2.2333

sering dilakukan. Kebiasaan atau cara khas mahasiswa dalam belajar disebut juga gaya kognitif. Setiap individu mempunyai ciri khas masing-masing, sehingga setiap individu memiliki karakteristik yang berbeda satu sama lainnya.

Perbedaan tersebut disebabkan oleh beberapa faktor dan salah satunya adalah gaya kognitif. Yildirim (2014: 210) said the term of cognitive style which is the intersection of common approaches can be defined as individual's attitude towards organization, process and approach information and stored by the brain, our approaches in problem solving are related with our cognitive thought. Gaya kognitif ditandai sebagai suatu sifat kognitif yang mungkin untuk menyatakan perbedaan kemampuan individu dalam kualitas pemecahan masalah. Uno (2006: 185), gaya kognitif merupakan cara mahasiswa yang khas dalam belajar, baik yang berkaitan dengan cara penerimaan dan pengolahan informasi, sikap terhadap informasi, maupun kebiasaan yang berkaitan dengan lingkungan belajar. Oleh karena itu, gaya kognitif memiliki peran penting pada kebiasaan mahasiswa dalam proses belajar.

Definisi gaya kognitif menurut Putra (2013: 2) adalah cara pandang individu terhadap suatu stimulus atau informasi dari luar. Ada seseorang bertindak secara cepat dalam beberapa situasi atas rangsangan walaupun keduanya mempunyai pengetahuan yang sama terhadap situasi tersebut. Hal ini, diperkuat oleh Froehlich (2003) yang mengatakan bahwa one group of children made decisions after briely looking at the figures, thus they were cognitively impulsive, while the other gropu carefully deliberated the choices before coming to a decision, thus they were cognitively reflective. Satu kelompok anak yang dalam membuat keputusan secara singkat setelah melihat gambar, sehingga mereka bergaya kognitif impulsif, sedangkan kelompok lainnya dengan hatihati memilih sebelum membuat keputusan, mereka bergaya kognitif reflektif.

Penelitian ini memfokuskan untuk menganalisis mahasiswa yang memiliki gaya kognitif reflektif dan impulsif. Mahasiswa yang memiliki gaya kognitif reflektif adalah mahasiswa yang memiliki karakteristik lambat dalam menjawab, tetapi cermat dan teliti, sehingga jawabannya cenderung benar. Sedangkan mahasiswa yang memiliki gaya kognitif impulsif adalah mahasiswa yang memiliki karakteristik cepat dalam menjawab, kurang cermat, sehingga jawabannya cenderung salah.

Gaya kognititf menunjukkan adanya variasi antar individu dalam pendekatannya terhadap satu tugas, tetapi variasi itu tidak menunjukkan tingkat intelegensi atau kemampuan tertentu. Sebagai karakteristik perilaku, karakteristik individu yang memiliki gaya kognitif sama belum tentu memiliki kemampuan yang sama. Apalagi individu yang memiliki gaya kognitif berbeda, kecenderungan perbedaan kemampuan yang dimilikinya lebih besar.

Gaya kognitif siswa merupakan hal penting yang harus diperhatikan guru waktu pembelajaran di kelas, karena memengaruhi prestasi akademik. Jantan (2014: 88) said cognitive styles have been identified to influence students' academic achievement. Berdasarkan beberapa pengertian gaya kognitif yang dikemukakan oleh para ahli, sehingga pada penelitian ini dapat dikatakan bahwa gaya kognitif adalah cara seseorang dalam memproses, berpikir, dan memecahkan masalah terhadap informasi dari luar yang bersifat konsisten dimana gaya kognitif yang dimaksud adalah gaya kognitif reflektif dan impulsif. Oleh karena itu, peneliti tertarik untuk mengkaji dan mendeskripsikan "Analisis Kemampuan Penalaran Matematis Mahasiswa Calon Guru Matematika dalam Menyelesaikan Masalah Aljabar Berdasarkan Gaya Kognitif Reflektif dan Impulsif." 
Formatif: Jurnal Ilmiah Pendidikan MIPA

Vol. 8, No. 2, Agustus 2018, pp. 119-128

p-ISSN: 2088-351X

e-ISSN: 2502-5457

DOI: http://dx.doi.org/10.30998/formatif.v8i2.2333

\section{METODE}

Penelitian ini bertujuan untuk mendeskripsikan kemampuan penalaran matematis mahasiswa calon guru dalam menyelesaikan masalah matematika non-rutin berdasarkan gaya kognitifnya. Komponen-komponen kemampuan penalaran matematis yang di ukur dalam penelitian ini adalah sebagai berikut,

\section{Analisis}

Menentukan, membicarakan, atau menggunakan hubungan-hubungan antar variabel atau obyek dalam situasi matematik, dan menyusun inferensi sahih dari informasi yang diberikan.

\section{Generalisasi}

Memperluas domain sehingga hasil pemikiran matematik atau pemecahan masalah dapat diterapkan secara lebih umum dan lebih luas.

\section{Sintesis}

Membuat hubungan antara elemen-elemen pengetahuan yang berbeda dengan representasi yang berkaitan. Menggabungkan fakta-fakta, konsep-konsep, dan prosedur-prosedur dalam menentukan hasil dan menggabungkan hasil tersebut untuk menentukan hasil yang lebih jauh.

\section{Justyfing}

Menarik kesimpulan untuk masalah yang diberikan.

\section{Penyelesaian Masalah Non-Rutin}

Menyelesaikan masalah dalam konteks matematik atau kehidupan sehari-hari dengan tujuan agar siswa terbiasa menghadapi masalah serupa, dan menerapkan fakta, konsep, dan prosedur dalam soal yang tidak biasa atau konteks kompleks.

Gaya kognitif pada penelitian ini dibagi menjadi dua, yaitu gaya kognitif reflektif dan impulsif (lihat Gambar. 1).

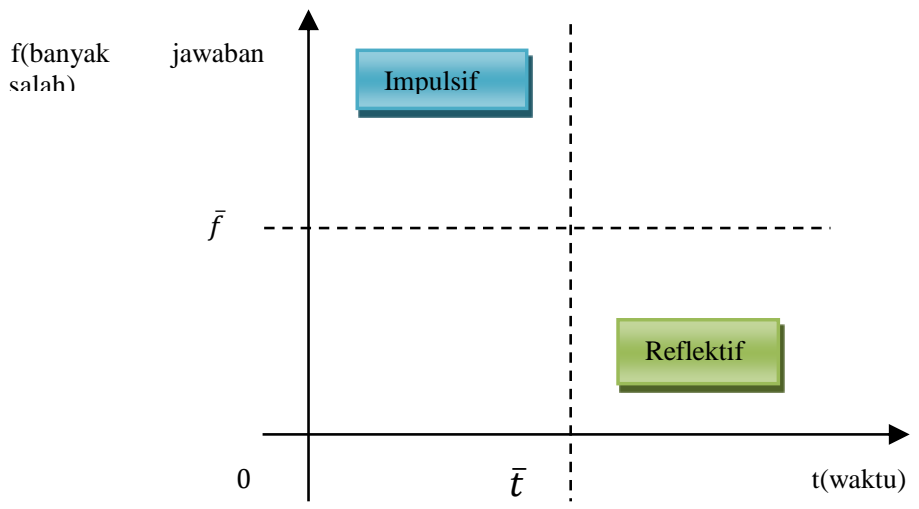

Gambar 1. Tempat Gaya Kognitif Reflektif dan Impulsif

Berdasarkan Gambar 1 mahasiswa yang bergaya kognitif reflektif dan impulsif berada pada kelompok II dan III Peneliti mempelajari dan mengungkap hasil deskripsi kemampuan penalaran matematis mahasiswa calon guru melalui data tertulis dan wawancara semi terstruktur. Dengan demikian, penelitian ini dikategorikan sebagai penelitian eksploratif dengan pendekatan kualitatif. Sebelum menguji kemampuan penalaran matematis mahasiswa calon guru, terlebih dahulu dipilih subjek penelitian. Subjek penelitian dipilih dengan menggunakan Matching Familiar Figure Test (MFFT) untuk mengkategorikan subjek berdasarkan gaya kognitif yang difokuskan pada penelitian ini. Setelah mendapatkan subjek penelitian, subjek diminta menyelesaikan 
Formatif: Jurnal Ilmiah Pendidikan MIPA

Vol. 8, No. 2, Agustus 2018, pp. 119-128

p-ISSN: 2088-351X

e-ISSN: 2502-5457

DOI: http://dx.doi.org/10.30998/formatif.v8i2.2333

masalah aljabar matematika non-rutin untuk melihat kemampuan penalaran matematisnya secara tertulis terlebih dahulu.

Selanjutnya, peneliti melakukan wawancara semi terstruktur terkait masalah aljabar matematika non-rutin yang telah diselesaikannya secara tertulis. Setelah memeroleh data yang dibutuhkan peneliti menganalisis data yang diperoleh sesuai dengan tujuan penelitian ini. Adapun langkah-langkah dalam penelitian ini adalah (1) tahap persiapan, pada langkah ini meliputi menyusun dan menyempurnakan draf proposal, dan menyusun draf instrument bantu. Setelah semua draf yang dibutuhkan selesai, peneliti melakukan validasi tes penyelesaian masalah matematika non-rutin ke ahli. Adapun penilaian kriteria yaitu terhadap penggunaan bahasa yang tertuang pada soal instrumen agar direvisi sehingga subjek tidak salah mengartika soal tersebut, (2) pemilihan subjek, subjek pada penelitian ini berdasarkan perbedaan gaya kognitif reflektif dan impulsif. Selanjutnya mahasiswa diberikan tes gaya kognitif dengan menggunakan MFFT untuk memilih dua subjek pada penelitian ini yaitu satu mahasiswa calon guru yang memiliki gaya kognitif reflektif dan satu mahasiswa calon guru yang memiliki gaya kognitif impulsif, (3) pengumpulan data diperoleh dengan cara memberikan masalah aljabar matematika non-rutin dan hasil wawancara masing-masing subjek, (4) melakukan analisis data pada penelitian ini dilakukan dengan beberapa tahapan, yaitu reduksi, penyajian dan penarikan simpulan.

\section{HASIL DAN PEMBAHASAN}

Pemilihan subjek penelitian dimulai dengan pemberian Matching Familiar Figure Test (MFFT). Peneliti memberikan MFFT pada mahasiswa calon guru pada Program Studi Pendidikan Matematika Fakultas Keguruan dan Ilmu Pendidikan, Universitas Muhammadiyah Prof. DR. HAMKA (UHAMKA) semester 2. Pada penelitian ini subjek yang peneliti pilih berdasarkan masing-masing gaya kognitif sebanyak 2 mahasiswa calon guru. Subjek penelitian terpilih dapat dilihat pada tabel 1.

Tabel 1. Daftar Subjek Penelitian

\begin{tabular}{|c|c|c|c|c|}
\hline Subjek & $\mathrm{L} / \mathbf{P}$ & Gaya Kognitif & $f$ & $t$ \\
\hline MFR & $\mathrm{L}$ & Reflektif & 9 & 26.57 \\
\hline MNA & $\mathrm{P}$ & Impulsif & 3 & 14.03 \\
\hline \multicolumn{5}{|l|}{ Ket: } \\
\hline$f_{t}^{f}$ & awa & $\begin{array}{l}\text { nng salah. } \\
\text { nakan siswa un }\end{array}$ & & \\
\hline
\end{tabular}

Setelah mendapatkan kedua mahasiswa calon guru sebagai subjek pada penelitian ini, peneliti memvalidasi instrumen penyelesaian masalah aljabar matematika non-rutin pada validator. Hasil validasi menyatakan bahwa instrumen kemampuan penalaran matematis pada penelitian ini layak digunakan dengan perbaikan. Secara umum, validator menyimpulkan instrumen penyelesaian masalah matematika non-rutin tersebut layak digunakan. Namun dengan perbaikan kata-kata pada kalimat soal. Adapun instrumen penyelesaian masalah matematika non-rutin yang digunakan dalam penelitian ini setelah mengalami perbaikan berdasarkan saran yang diberikan oleh validator ditunjukkan dalam gambar 2. 
Formatif: Jurnal Ilmiah Pendidikan MIPA

Vol. 8, No. 2, Agustus 2018, pp. 119-128

p-ISSN: 2088-351X

e-ISSN: 2502-5457

DOI: http://dx.doi.org/10.30998/formatif.v8i2.2333

\section{TUGAS PENYELESAIAN MASALAH ALJABAR}

Ratna ingin membungkus sebuah kado untuk temannya yang berulang tahun. Ia membutuhkan sebuah kotak tanpa tutup yang beralaskan persegi. Luas sebuah kotak tanpa tutup yang alasnya persegi adalah $432 \mathrm{~cm}^{2}$. Tentukan panjang rusuk kotak tersebut sehingga volumenya maksimum!

\section{Gambar 2. Instrumen Penelitian}

\section{Deskripsi Kemampuan Penalaran Matematis Mahasiswa Calon Guru}

Untuk mengetahui kemampuan penalaran mahasiswa dalam menyelesaikan masalah matematika non-rutin, peneliti memberikan tes penyelesaian masalah aljabar matematika non-rutin dan melakukan wawancara semi terstruktur pada setiap subjek. Peneliti memberikan kode untuk memaparkan hasil deskripsi kemampuan penalaran matematis setiap subjek, yaitu (1) Mahasiswa yang memiliki gaya kognitif reflektif dengan kode SR, dan (2) Mahasiswa yang memiliki gaya kognitif lambat-kurang cepat dengan kode SI.

Adapun komponen-komponen kemampuan penalaran matematis pada penelitian ini yaitu analisis, generalisasi, sintesis, justifying dan penyelesaian masalah non-rutin.

\section{Hasil Analisis Kemampuan Penalaran Matematis Subjek dengan Gaya Kognitif Reflektif (SR).}

Subjek SR yang memiliki gaya kognitif reflektif menyelesaikan masalah non rutin yang diberikan oleh peneliti selama kurang lebih 60 menit. Adapun hasil analisis kemampuan penalaran matematis SR berdasarkan komponen-komponen kemampuan penalaran matematis pada penelitian ini, sebagai berikut.

\section{Analisis}

Paparan kemampuan penalaran matematis SR pada komponen analisis, yaitu SR mampu menggunakan hubungan antara informasi yang diketahui dengan informasi yang ditanyakan. SR menggunakan analisis berupa gambar untuk mempermudah informasi yang tersedia dan menggunakan rumus luas permukaan kubus berdasarkan data yang diketahui pada soal. Selain itu, SR berusaha menggunakan konsep turunan dalam menyelesaikan masalah aljabar matematika non rutin tersebut. Walaupun, SR belum tepat menghubungkannya ke dalam situasi matematis berdasarkan informasi yang diberikan pada soal.

\section{Generalisasi}

Paparan kemampuan penalaran matematis SR pada komponen generalisasi, yaitu SR belum mampu memperluas atau menggeneralisasikan rumus luas permukaan kubus tanpa tutup sehingga hasil pemikirannya hanya terpaku dalam luas permukaan kubus saja. Belum mampu melihat generalisasi dengan konsep yang lain.

\section{Sintesis}

Paparan kemampuan penalaran matematis SR pada komponen sintesis, yaitu SR membuat hubungan antara pengetahuan yang berbeda yaitu berdasarkan informasi atau data yang tersedia dengan representasi gambar. Selanjutnya, SR menggabungkan fakta-fakta, konsep-konsep dan prosedur-prosedur volume dan luas permukaan kubus dalam menentukan penyelesaian masalah yang diberikan dan menggabungkan hasil 
informasi yang ada untuk memperoleh penyelesaian. Akan tetapi, konsep yang digunakan oleh SR masih belum diterapkan dengan baik, sehingga penyelesaian masalah yang diperoleh masih kurang tepat.

\section{Justifying}

Paparan kemampuan penalaran matematis SR pada komponen justifying, yaitu SR belum mampu menarik kesimpulan untuk penyelesaian masalah aljabar matematika non rutin yang diberikan. SR hanya mampu mengidentifikasi dari informasi yang ada. Belum adanya hasil simpulan lebih lanjut dari informasi yang ada.

\section{Penyelesaian Masalah Non-Rutin}

Paparan kemampuan penalaran matematis SR pada komponen penyelesaian masalah non rutin, yaitu SR belum mampu menyelesaikan masalah dalam konteks matematis maupun kehidupan sehari-hari. Hal ini, disebabkan karena SR belum mampu menerapkan fakta, konsep dan prosedur volume dan luas permukaan kubus dalam menyelesaikan masalah matematika non rutin. Belum mampu mengaitkan permasalahan dengan informasi yang ada.

\section{Paparan Hasil Analisis Kemampuan Penalaran Matematis Subjek dengan Gaya Kognitif Impulsif (SI)}

Subjek SI yang memiliki gaya kognitif reflektif menyelesaikan masalah non rutin yang diberikan oleh peneliti selama kurang lebih 60 menit. Adapun hasil analisis kemampuan penalaran matematis SI berdasarkan komponen-komponen kemampuan penalaran matematis pada penelitian ini, sebagai berikut.

\section{Analisis}

Paparan kemampuan penalaran matematis SI pada komponen analisis, yaitu SI mampu menggunakan hubungan antara informasi yang diketahui dengan informasi yang ditanyakan. SI menggunakan analisis berupa gambar untuk mempermudah menyelesaikan masalah yang diberikan dan menggunakan rumus luas permukaan kubus tanpa tutup berdasarkan data yang diketahui pada soal. Akan tetapi, SI hanya berusaha memperoleh panjang rusuk dari konsep luas permukaan kubus tanpa tutup dan tidak mempertimbangkan syarat lainnya dalam menyelesaikan masalah tersebut yaitu panjang rusuk sehingga volume kubus tanpa tutup tersebut bernilai maksimal.

\section{Generalisasi}

Paparan kemampuan penalaran matematis SI pada komponen generalisasi, yaitu SI belum mampu memperluas atau menggeneralisasikan rumus luas permukaan kubus tanpa tutup sehingga belum bisa mengaitkannya dengan volume maksimal kubus. Subjek belum mampu melihat generalisasi dari hasil perhitungan luas permukaan kubus dengan volume maksimum. Sehingga subjek masih kurang tepat untuk menjawab dari informasi yang telah disediakan.

\section{Sintesis}

Paparan kemampuan penalaran matematis SI pada komponen sintesis, yaitu SI membuat hubungan berdasarkan informasi atau data yang tersedia dengan representasi gambar. Selanjutnya, SI mencoba menghubungkan fakta-fakta, konsepkonsep dan prosedur-prosedur luas permukaan kubus secara umum dengan luas permukaan kubus tanpa tutup dalam menentukan penyelesaian masalah yang diberikan. Akan tetapi, konsep yang digunakan oleh SI masih ada yang terlewatkan, sehingga penyelesaian masalah yang diperoleh masih kurang tepat. 
Formatif: Jurnal Ilmiah Pendidikan MIPA

Vol. 8, No. 2, Agustus 2018, pp. 119-128

p-ISSN: 2088-351X

e-ISSN: 2502-5457

DOI: http://dx.doi.org/10.30998/formatif.v8i2.2333

\section{Justifying}

Paparan kemampuan penalaran matematis SI pada komponen justifying, yaitu SI belum mampu menarik simpulan untuk penyelesaian masalah matematika non-rutin yang diberikan.

\section{Penyelesaian Masalah Non-Rutin}

Paparan kemampuan penalaran matematis SI pada komponen penyelesaian masalah non-rutin, yaitu SI belum mampu menyelesaikan masalah matematika nonrutin yang dikaitkan dengan kehidupan sehari-hari. Hal ini, disebabkan karena SI belum mampu menerapkan fakta, konsep dan prosedur yang tepat untuk diterapkan pada soal yang diberikan.

Pada mahasiswa calon guru matematika yang memiliki gaya kognitif reflektif, kemampuan penalaran matematisnya dalam menyelesaikan masalah aljabar yang diberikan, yaitu waktu yang diperlukan oleh mahasiswa dalam menganalisis instrumen yang diberikan sekitar 30 menit. Hal tersebut sejalan dengan pendapat Sulisawati (2013) menyatakan bahwa subjek dengan gaya kognitif refletif mengalami kebingunan ketika menentukan strategi yang akan digunakannya untuk menyelesaikan masalah karena subjek perlu mengingat-ingat dan mencocokkan beberapa penyelesaian masalah yang pernah digunakan sebelumnya untuk bisa menemukan cara agar dapat menyelesaikan soal yang diberikan. Selain itu, Mahasiswa bergaya kognitif reflektif ini mampu mengeneralisasikan soal dengan pengetahuan yang lebih umum walaupun pada simpulan akhirnya tidak mampu menjawab soal dengan tepat. Seperti halnya yang dikatakan oleh Aburrahman (1999) yang mengatakan bahwa anak yang memiliiki gaya kognitif reflektif cenderung menjawab persoalan secara lebih lambat tetapi hanya membuat sedikit kesalahan.

Deskripsi kemampuan penalaran matematis mahasiswa calon guru dalam menyelesaikan masalah matematika berdasarkan gaya kognitif impulsif, yaitu mahasiswa tersebut terlihat terburu-buru dalam menganalisis solusi yang dapat digunakan untuk menyelesaikan masalah yang diberikan. Hal ini, diperkuat ketika peneliti mewawancara subjek. Sesuai dengan yang diungkapkan oleh Kenny (2007) yaitu subjek impulsif lebih mementingkan kecepatan menjawab daripada keakuratan jawaban.

\section{PENUTUP}

Berdasarkan hasil deskripsi penelitian maka dapat disimpulkan bahwa kemampuan penalaran matematis mahasiswa calon guru dalam menyelesaikan masalah aljabar berdasarkan gaya kognitif reflektif, subjek mencoba menyelesaikan masalah matematika non-rutin yang diberikan dengan menggunakan representasi gambar kubus untuk mempermudah perhitungan yang ditanyakan. Subjek menggunakan hubungan gambar dengan informasi yang telah diketahui sebelumnya dan menyusun informasi yang telah diberikan dengan menggunakan rumus luas permukaan kubus tanpa tutup. Akan tetapi, subjek tidak mampu memperluas rumus permukaan luas kubus yang telah diketahui sebelumnya dan tidak mampu menggeneralisasikannya. Subjek tidak menghubungkan antara elemen pengetahuan yang berbeda dengan representasi yang berkaitan, menggabungkan fakta-fakta, konsep-konsep, dan prosedur-prosedur dalam menentukan penyelesaian masalah yang diberikan. Subjek menggunakan konsep luas permukaan kubus dengan menggunakan konsep turunan secara menyeluruh walaupun subjek salah dalam menyelesaikan masalah yang diberikan. 
Formatif: Jurnal Ilmiah Pendidikan MIPA

Vol. 8, No. 2, Agustus 2018, pp. 119-128

p-ISSN: 2088-351X

e-ISSN: 2502-5457

DOI: http://dx.doi.org/10.30998/formatif.v8i2.2333

Kemampuan penalaran matematis mahasiswa calon guru dalam menyelesaikan masalah aljabar berdasarkan gaya kognitif impulsif, subjek menggunakan hubungan antara informasi yang diketahui dan ditanyakan pada soal. Berdasarkan informasi tersebut, subjek menggunakan gambar untuk mempermudahnya dalam menyelesaikan masalah yang diberikan. Melalui gambar, subjek berusaha menghubungkan konsep luas permukaan kubus secara umum dengan luas kubus tanpa tutup. Akan tetapi, subjek belum menggeneralisasikan konsep yang telah diperolehnya untuk mengaitkannya dalam menentukan panjang rusuk sehingga volume yang dihasilkan maksimal. Hal ini mengakibatkan subjek belum mampu menarik simpulan untuk penyelesaian masalah matematika non rutin yang diberikan. Belum mampunya subjek dalam menerapkan fakta, konsep dan prosedur membuatnya belum mampu menyelesaikan masalah matematika non rutin yang diberikan.

\section{DAFTAR PUSTAKA}

Abdurrahman, M. (1999). Pendidikan Bagi Anak Berkesulitan Belajar. Jakarta: Rineka Cipta.

Castro, Belinda de. (2004). Pre-service teachers' mathematical reasoning as an imperative for codified conceptual pedagogy in algebra: A case study in teacher education. Journal of Asia Pacific Education Vol.5 No.2

Froehlich. (2003). Cognitive Styles: A Review of the Major Theories and Their Application to Information Seeking in Virtual Environments. (Online). Tersedia http://www.personal.kent.edu/ plucasst/Cognitive\%20Styles.pdf

Hidayat, W. (2014). Penerapan Pembelajaran MEAs Terhadap Peningkatan Daya Matematik Siswa SMA. Prosiding Seminar Nasional Program Pascasarjana Pendidikan Matematika STKIP Siliwangi Bandung.

Jantan, Ramlah Bt. (2014). Relation between Students' Cognitive Style (Field-Dependent and Field-Independent Cognitive Styles) with their Mathematic Achievement in Primary School. International Journal of Humanities Social Science and Education (IJHSSE). Vol.1 Issue 10. ISSN 2349-0373 (Print) \& ISSN 23490381 (Online). www.arcjournals.org.

Leonard, L. (2013). Kajian peran konsistensi diri terhadap prestasi belajar matematika. Formatif: Jurnal Ilmiah Pendidikan MIPA, 3(2), 97-104. http://doi.org/http://dx.doi.org/10.30998/formatif.v3i2.116

Putra, A. (2013). Jurnal Magister Kedokteran Keluarga Vol 1 No 1 2013. (Online). Tersedia http://jurnal.pasca.uns.ac.id

Sa'adah, Widayanti N,. (2010). Peningkatan Kemampuan Penalaran Matematis Siswa Kelas VIII SMP Negeri 3 Banguntapan dalam Pembelajaran Matematika Melalui Pendekatan Pendidikan Matematika Realistik Indonesia (PMRI) (Skripsi diterbitkan). Universitas Negeri Yogyakarta.

Sinaga, Nurul Afni. (2016). Pengembangan Tes Kemampuan Pemecahan Masalah dan Penalaran Matematika Siswa SMP Kelas VIII. PHYTHAGORAS: Jurnal Pendidikan Matematika Volume 11 No.2. (Online). Tersedia http://journal.uny.ac.id/index.php/phythagoras.

Sulisawati. (2013). Pengaturan Diri Siswa SMP dengan Gaya Kognitif Reflektif-Impulsif dalam Menyelesaikan Masalah Aljabar (Tesis magister pendidikan tidak diterbitkan). Universitas Negeri Surabaya.

Sumarmo, U. (2013). Kumpulan Makalah Berpikir dan Disposisi Matematik serta Pembelajarannya. UPI Bandung. Tidak diterbitkan. 
Formatif: Jurnal Ilmiah Pendidikan MIPA

Vol. 8, No. 2, Agustus 2018, pp. 119-128

p-ISSN: 2088-351X

e-ISSN: 2502-5457

DOI: http://dx.doi.org/10.30998/formatif.v8i2.2333

Uno, H.B,. (2006). Orientasi Baru dalam Psikologi Pembelajaran. Jakarta: PT. Bumi Aksara

Widyasari, N. (2013). Meningkatkan Kemampuan Penalaran dan Disposisi Matematis Siswa SM P Melalui Pendekatan Metaphorical Thinking. (Tesis). Sekolah Pascasarjana, Universitas Pendidikan Indonesia, Bandung.

Yildirim, Isul. Rengin Zengel. (2014). The impact of cognitive styles on design students' spatial knowledge from virtual environments. The Turkish Online Journal of Education Technology, 13 (3). 